\title{
Erratum to: Linking calcification by exotic snails to stream inorganic carbon cycling
}

\author{
Erin R. Hotchkiss $\cdot$ Robert O. Hall Jr.
}

Published online: 6 February 2010

(C) Springer-Verlag 2010

\section{Erratum to: Oecologia}

DOI 10.1007/s00442-009-1536-1

Unfortunately, Eq. 10 has been incorrectly published, the correct version of Eq. 10 is given below:

$\mathrm{CO}_{2}$ flux $\left(\mathrm{mmol} \mathrm{m}^{-2} \mathrm{~min}^{-1}\right)=k_{\mathrm{CO}_{2}}\left(\left(\rho \mathrm{CO}_{2} \times K_{\mathrm{H}}\right)-\left[\mathrm{CO}_{2}\right]_{\mathrm{sat}}\right)$

The online version of the original article can be found under doi:10.1007/s00442-009-1536-1.

E. R. Hotchkiss ( $\square)$

Program in Ecology, University of Wyoming,

Laramie, WY 82071-3166, USA

e-mail: ehotchki@uwyo.edu

E. R. Hotchkiss - R. O. Hall Jr.

Department of Zoology and Physiology,

University of Wyoming, Laramie, WY 82071-3166, USA 